\title{
骨修復材料としての超高分子量ポリエチレン／酸化チタン複合体の調製
}

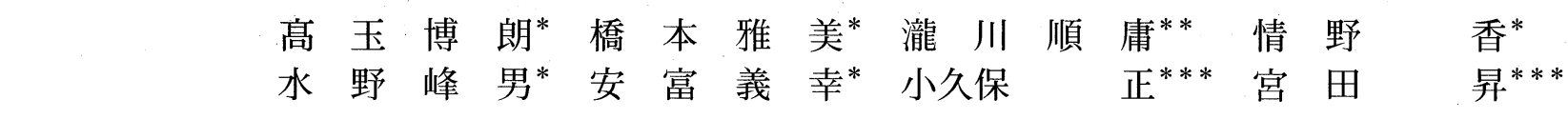

\section{Preparation of Ultra-High Molecular Weight Polyethylene/Titanium Oxide Composites for Bone Repairing Materials}

\author{
by \\ Hiroaki Takadama *, Masami Hashimoto *, Yorinobu Takigawa ${ }^{* *}$, Kaori Jono *, \\ Mineo Mizuno ${ }^{*}$, Yoshiyuki Yasutomi ${ }^{*}$, Tadashi Kokubo ${ }^{* * *}$ and Noboru Mryata ${ }^{* * *}$
}

\begin{abstract}
he essential requirement for an artificial material to show bone-bonding ability (bioactivity) is the formation of a bonelike apatite layer on its surface in the living body. An acellular simulated body fluid (SBF) with ion concentrations nearly equal to those in human blood plasma was shown to reproduce in vivo bonelike apatite formation on bioactive materials. Recently, new bone-repairing materials with bioactivity and mechanical properties analogous to those of natural bone have been strongly desired to be developed. Therefore, inorganic-organic composites are considered to be suitable for this purpose. It has been reported that titanium oxide with an anatase structure $\left(\mathrm{TiO}_{2}\right)$ shows high bioactivity, and that ultra-high molecular weight polyethylene (PE) shows good biocompatibility. In the present study, bioactive $\mathrm{PE} / \mathrm{TiO}_{2}$ composites were prepared by hot press. The composites were prepared from the powder mixtures of $\mathrm{PE}(90 \mathrm{vol} \%)$ and $\mathrm{TiO}_{2}(10 \mathrm{vol} \%)$ obtained by three different mixing processes, 1$)$ an agate mortar mixing, 2) ball milling and 3)Theta-composer mixing. Their bioactivity and the effects of the mixing on the mechanical properties of the composites were investigated. The Theta-composer can prepare the composite particles of PE covered uniformly with the $\mathrm{TiO}_{2}$ powders without any agglomerations of $\mathrm{TiO}_{2}$. After hot press, the composites prepared from Theta-composer powder mixture gave the most uniform distribution of the $\mathrm{TiO}_{2}$ powder in the $\mathrm{PE}$ matrix. All of these composites formed the apatite layer on their surfaces after soaked in SBF. The composite prepared from Theta-composer powder mixture showed the highest bending strength. These composites show high extensibility. These composites are considered to be useful as bone-repairing materials.
\end{abstract}

Key words : Bioactivity, Apatite, Simulated body fluid (SBF), Titanium oxide, Anatase, Ultra-high molecular weight polyethylene, Inorganic-organic composite, Theta-composer

\section{1 緒言}

一般に人工材料を骨の欠損部に埋入すると, 生体はそ れを線維性被膜で取り囲み, 周囲の骨から隔離しようと する.しかし 1970 年頃, 線維性被膜に覆われることな く骨と自然に結合するある種のガラスが発見された。こ のガラスは Bioglass ${ }^{\circledR 1)}$ と名付けられ, その後, 焼結水酸 アパタイト $(\mathrm{HAp})^{2)}$ や結晶化ガラス Cerabone $\left.{ }^{\circledast} \mathrm{A}-\mathrm{W}^{3}\right)$ 等, 少数ながら骨と自然に結合する生体活性セラミックスが 開発された。続いて; チタン金属に $\mathrm{NaOH}$ 処理等の簡単 な化学処理を行い, その表面にアモルファスチタン酸ナ トリウム層 ${ }^{4)}$ を, あるいはさらに温水処理してアナター 不構造の酸化チタン層 ${ }^{5}$ を形成させることにより, 生体 活性チタン金属が調製できることも報告された。

これら生体活性材料は，一般的に，生体内でその表面 に骨類似アパタイト層を形成し，それを介して骨と自然 に結合する. 即ち, 人工材料が骨と結合するための必須
条件が，その表面にアパタイト層を形成することである ことが明らかにされた。吕らに，小久保らにより，この アパタイト形成が, ヒトの体液にほぼ等しい無機イオン 濃度を有する擬似体液 $(\mathrm{SBF})$ 中でも再現できる7 ${ }^{7}$ ことが 示され，このSBF を用いて新規材料の生体活性発現の有 無をin vitro で簡便に評価できるようになった。

しかし，これまでに開発された骨修復材料のほとんど は, 金属やセラミックス材料からなるため, その力学的 特性が骨のそれと大きく異なっている。そのため, 骨と 並列に埋入すると，周囲の骨に応力が加わらないために 周囲の骨がやせてしまい，ひいては長期固定性が悪くな るという問題点を抱えている。，そこで，より天然骨に近 い力学的特性を有する無機一有機複合体からなる人工骨 が開発された。攵の代表的なものに，高密度ポリエチレ ン (HDPE) 中に無機フィラーとして HAp, Bioglass ${ }^{\circledR}$, 結晶化ガラス $\mathrm{A}-\mathrm{W}^{\circledR}$ を分散させた HAPEX ${ }^{\circledR 8}$, , 9) HDPE/

\footnotetext{
$\dagger \quad$ 原稿受理 平成 14 年 9 月 17 日 Received Sep. 17, 2002

* (財) ファインセラミックスセンター T456-8587 名古屋市熱田区六野, Japan Fine Ceramics Center (JFCC), Atsuta-ku, Nagoya, 456-8587

** 正 会 員 (財) ファインセラミツクスセンター T456-8587 名古屋市熱田区六野, Japan Fine Ceramics Center (JFCC), Atsuta-ku, Nagoya, 456-8587

*** 正 会 員 京都大学工学研究科材料化学専攻 T606-8501 京都市左京区吉田本町, Dept. of Material Chem., Graduate School of Eng., Kyoto Univ., Sakyo-ku, Kyoto, 606-8501
} 
Bioglass ${ }^{\circledR 10)} \mathrm{HDPE} / \mathrm{A}-\mathrm{W}^{\circledR 9}$ 等がある。しかし，これらの 力学的特性は骨のそれに拉よんでおらず，またその塑性 変形量は HDPE 単体に比べて非常に小さく，ぜい性破壊 するのが現状である. 学修復材料としては最終的に破断 に至らない材料か望まれるので, フィラー充填量を母材 の特性を大きく損なわない程度にすることも重要である. 一方, アナタース型酸化チタンは高い生体活性 ${ }^{5)}$ を示し; その曲け強度や弾性率は Bioglass ${ }^{\circledR}$ や HAp よりも大きい ため, ${ }^{6)}$ 11) アナタース型酸化チタンをフィラーとして用い れば，より天然骨に類似した力学的特性を有する複合体 が得られると期待される。.また Bioglass ${ }^{\circledR}$ や A-W ${ }^{\circledR}$ は生 体環境下で一部溶解するため, これらをフィラーとして 用いた HDPE/Bioglass ${ }^{\circledR}$ や HDPE/A-W ${ }^{\circledR}$ は長期的に強度 を維持できないという欠点を有しているが, 酸化チタン は溶出しないので強度低下を生じないと期待される。さ らに，アパタイト形成能に関しても，ミクロン粒子のフ イラーを用いた $\mathrm{HAPEX}^{\circledR}$ 等とは異なり,ナノ粒子の酸化 チタンをフィラーに用いれば，表面に露出する酸化チタ ンの総表面積が増大し, 高いアパタイト形成能が期待で きる。また，緻密骨の修復をねらった人工骨として最も 多く使用されているのは, 人工椎体, 椎弓および椎間ス ペーサー等である。この部位では繰り返し応力や衝撃や 摩擦等にさらされるため, HDPE よりも耐衝撃性や耐摩 耗性等に優れる超高分子量ポリエチレンの方が, 複合体 の母材として利用するのには好ましいと言える.

そこで本研究では, 超高分子量ポリエチレンとアナタ 一ス型酸化チタンを用いて, アパタイト形成能と天然骨 に類似した力学的特性を有するポリエチレン/酸化チタ ン $\left(\mathrm{PE} / \mathrm{TiO}_{2}\right)$ 複合材料の作製条件を検討し，そのアパ タイト形成能抢よび力学的特性について調べた.

\section{2 実 験 方 法}

\section{$2 \cdot 1 \mathrm{PE} / \mathrm{TiO}_{2}$ 複合体の調製}

原料粉末には, 平均粒径 $200 \mathrm{~nm}$ の酸化チタン $\left(\mathrm{TiO}_{2}\right.$ : アナタース型, 石原産業(森)）と超高分子量ポリエチレン (PE：平均分子量約 500000 , 平均粒径 $45 \mu \mathrm{m}$, Aldrich) を使用した。孚の混合割合は，十分な伸張性を示す複合 体を得るために, $\mathrm{PE}: 90 \mathrm{vol} \%, \mathrm{TiO}_{2}: 10 \mathrm{vol} \%$ とした。 こ の組成になるように秤量した両粉末を次の 3 種の異なる 方法を用いて混合した。

(1) めのう乳鉢による混合：めのう乳鉢を用いて 30 分間混合した。

（2）ボールミルによる混合：エタノール中に両粉末を 祬化ケイ素ボールと共に分散させ，ボールミルで 12 時間 混合した。得られた混合溶液を振動乾燥機（VU-30, 中 央化工機株)）を用いて温度 $75^{\circ} \mathrm{C}$ で真空乾燥させ，得られ た乾燥粉体を乳鉢でつぶし，目の開き $150 \mu \mathrm{m}$ のふるいに かけ，混合粉体を調製した。

(3) 粒子複合化装置による混合：機械的粒子複合化 装置（シータコンポーザー：THC-LAB200，(株徳寿工作 所）を用い, ローター回転数 $2100 \mathrm{rpm}$, 容器回転数 $50 \mathrm{rpm}$ で 45 分間混合した. シータコンポーザーの混合 原理を Fig. 1 に示す。この装置では, 容器内部のシータ

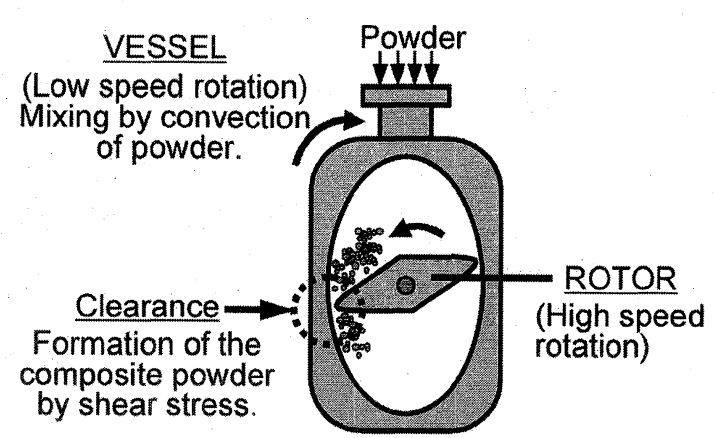

Fig. 1. Schematic drawing of the Theta-composer for the preparation of composite particles.

型のだ円ローターが高速回転すると同時に容器自体も反 対方向に低速回転する。攵のため, 容器内に投入された 粉体はローターと容器内壁の間隙部にて圧密, せん断力 を繰り返し受けることで複合化され，最終的に被覆型の 複合微粒子が作製される。

上記 3 種の混合法で調製した混合粉体をそれぞれ金型 に入れ，ホットプレス付き小型䨌囲気炉（FVPHP-R-10 FRET-30, 富士電波工業(侏) で, プレス負荷 $5 \mathrm{MPa}$, ア ルゴン雾囲気中, $5^{\circ} \mathrm{C} / \mathrm{min}$ で昇温し, $180^{\circ} \mathrm{C}$ で 3 時間保 持した後, 炉内で放冷し, $\mathrm{PE} / \mathrm{TiO}_{2}$ 複合体を調製した。

\section{$2 \cdot 2 \mathrm{PE} / \mathrm{TiO}_{2}$ 複合体の $\mathrm{SBF}$ 浸漬}

調製した複合体から $10 \times 10 \times 2 \mathrm{~mm}^{3}$ の試験片を切り出 し, 蒸留水で洗浄乾燥後, これをアパタイト形成能評価 用の試料とした。これとは別に, 表面を\#120の研磨シ 一トで研磨後, 哌留水で洗浄乾燥させた試料も用意した。 これら試料を, $\mathrm{SBF}^{7)}\left(\mathrm{Na}^{+} 142.0, \mathrm{~K}^{+} 5.0, \mathrm{Mg}^{2+} 1.5, \mathrm{Ca}^{2+}\right.$ $2.5, \mathrm{Cl}^{-} 147.8, \mathrm{HCO}_{3}{ }^{-} 4.2, \mathrm{HPO}_{4}{ }^{2-} 1.0, \mathrm{SO}_{4}{ }^{2-} 0.5 \mathrm{mM}$ ) $20 \mathrm{ml}$ 中に $36.5^{\circ} \mathrm{C}$ で浸漬し, 複合体表面へのアパタイト形 成の有無を調べた. $\mathrm{SBF}$ は, 特級試薬の $\mathrm{NaCl}, \mathrm{NaHCO}_{3}$, $\mathrm{KCl}, \mathrm{K}_{2} \mathrm{HPO}_{4} \cdot 3 \mathrm{H}_{2} \mathrm{O}, \mathrm{MgCl}_{2} \cdot 6 \mathrm{H}_{2} \mathrm{O}, \mathrm{CaCl}_{2}, \mathrm{Na}_{2} \mathrm{SO}_{4}$ （ナカライテスク(㑣)）を蒸留水に溶解することにより調製 し，元の $\mathrm{pH}$ をトリス（ヒドロキシメチル）アミノメタ ン $\left(\left(\mathrm{CH}_{2} \mathrm{OH}\right)_{3} \mathrm{CNH}_{2}\right)$ と $1.0 \mathrm{M}$ の $\mathrm{HCl}$ (ナカライテスク

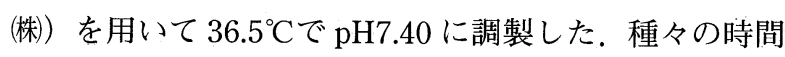
浸漬後, 試料を SBF から取り出し, 蒸留水で洗浄後, クリーンベンチ内で乾燥させた。

\subsection{SBF 浸清後の $\mathrm{PE} / \mathrm{TiO}_{2}$ 複合体表面および SBF の分析}

浸漬後のアパタイト形成の有無は, 複合体表面を薄膜 $\mathrm{X}$ 線回折（TF-XRD：Model-265A，(㑣りガク製），フーリ 工変換赤外分光分析 (FT-IR: System 2000FT-IR, PERKIN ELMER 製) 打よび電解放出形走查型電子顕微鏡（FESEM：JSM-6330F, JEOL 製）により分析した. TF$\mathrm{XRD}$ 測定では, X 線源として $\mathrm{CuK} \alpha$ 線を用い, 出力 $40 \mathrm{kV}, 40 \mathrm{~mA}$ ，スキャンスピード $2 \theta=2 \% \mathrm{~min}$ とした. 各試料表面からアパタイトのスペクトルが TF-XRD によ り検出される最短の時間を調べ，それをその複合体にお けるアパタイト形成までの誘導期間とし, 試料間のアパ タイト形成能を比較した。また，複合体を浸漬した後の $\mathrm{SBF}$ 中の元素濃度を, 電荷注入型 (CID) 検出高周波誘 
導結合プラズマ発光分析装置（ICP：IRIS Advantage, 日本ジャーレル・アッシュ(株) により測定した。

\section{$2 \cdot 4 \mathrm{PE} / \mathrm{TiO}_{2}$ 複合体の力学的特性評価}

調製した複合体から試験片を切り出し，\#400で䂺磨 後，大きさ $40 \times 10 \times 4 \mathrm{~mm}^{3}$ の角柱曲け試験片を作製した。 万能材料試験機（インストロン社製 5582 型）を用いて 3 点曲げ試験を行い，荷重一変位曲線を求めた。支点間 距離を $30 \mathrm{~mm}$ ，クロスヘッド速度を $1.0 \mathrm{~mm} / \mathrm{min} と し ，$ $40 \times 10 \mathrm{~mm}^{2}$ の面に引張応力が加わるように荷重を加え た。すべての試験は室温，大気雰囲気中で行った。試験 は 1 条件につき 5 個ずつ行った。荷重一変位曲線の初期 の線形領域の傾きから弾性率を算出した。

\section{3 実 験 結 果}

\section{$3 \cdot 1 \mathrm{PE} / \mathrm{TiO}_{2}$ 混合粉体}

めのう乳鉢あるいはボールミル混合によって調製した 混合粉体を $\mathrm{SEM}$ 観察すると，原料粉末の $\mathrm{PE}$ と $\mathrm{TiO}_{2}$ が ほぼ均一に混合されていることが確認できたが，その中 には極少量の $\mathrm{TiO}_{2}$ の凝集物も観察された。その凝集物の 大きさは，ボールミル混合で形成されたもののほうが小さ かった。一方，シータコンポーザー混合により，Fig. 2 に 示されるような $\mathrm{TiO}_{2}$ で被覆された $\mathrm{PE}$ 複合粒子が作製で き，凝集物は全く見られなかった。

\section{$3 \cdot 2$ 未研磨 $\mathrm{PE} / \mathrm{TiO}_{2}$ 複合体}

Fig. 3 にSBF 浸漬後の複合体表面の SEM 写真を示 す. SBFに浸漬後，いずれの混合粉体から調製した複合 体表面にも粒子状の形成物が観察された。TF-XRD 測定
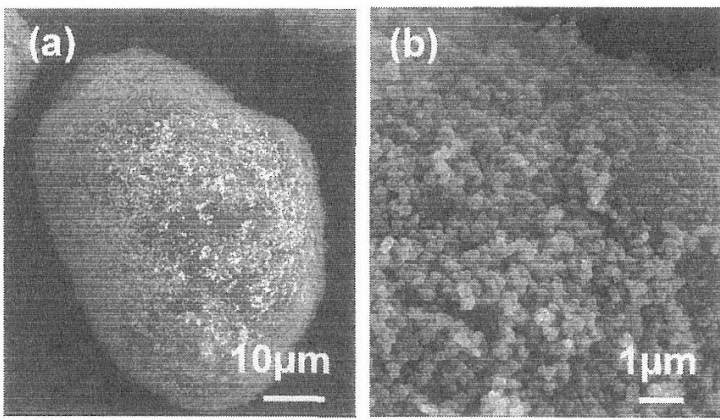

Fig. 2. The SEM images in (a) low and (b) high magnifications of the composite particles prepared by Theta-composer. The composite particles of $\mathrm{PE}$ powder are covered with $\mathrm{TiO}_{2}$ powder.
の結果，SBF 浸漬後の複合体表面からテパタイトに帰属 されるブロードなピークが検出された (Fig. 4)，FT-IRに より，浸漬後の表面から $560 ， 610$ 扎よび 1060，1130 $\mathrm{cm}^{-1}$ 付近にアパタイトの P-O 結合に帰属されるピークと, $1450 \mathrm{~cm}^{-1}$ 付近に炭酸の C-O 結合に帰属されるピークが検

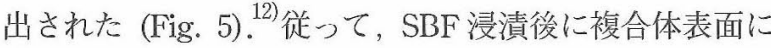
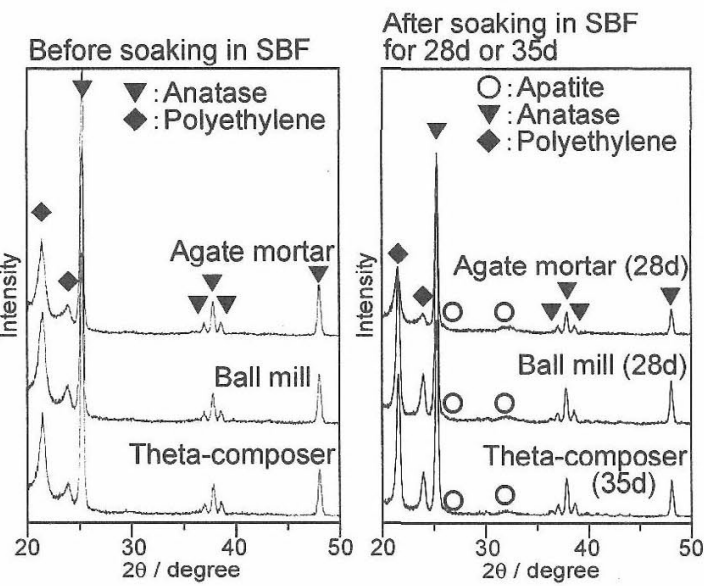

Fig. 4. XRD patterns of the surfaces of the $\mathrm{PE} / \mathrm{TiO}_{2}$ composites prepared through three different mixing processes. The as-prepared composites were soaked in SBF for 28 or $35 \mathrm{~d}$.

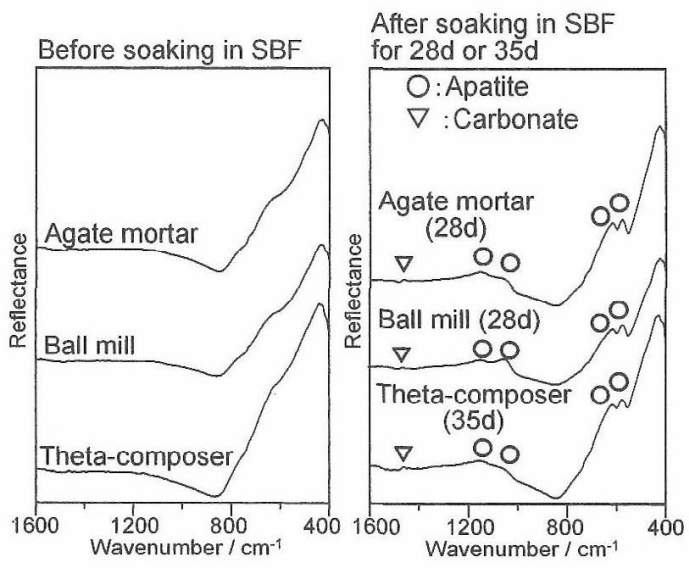

Fig. 5. FT-IR patterns of the surfaces of the $\mathrm{PE} / \mathrm{TiO}_{2}$ composites prepared through three different mixing processes. The as-prepared composites were soaked in SBF for 28 or $35 \mathrm{~d}$.
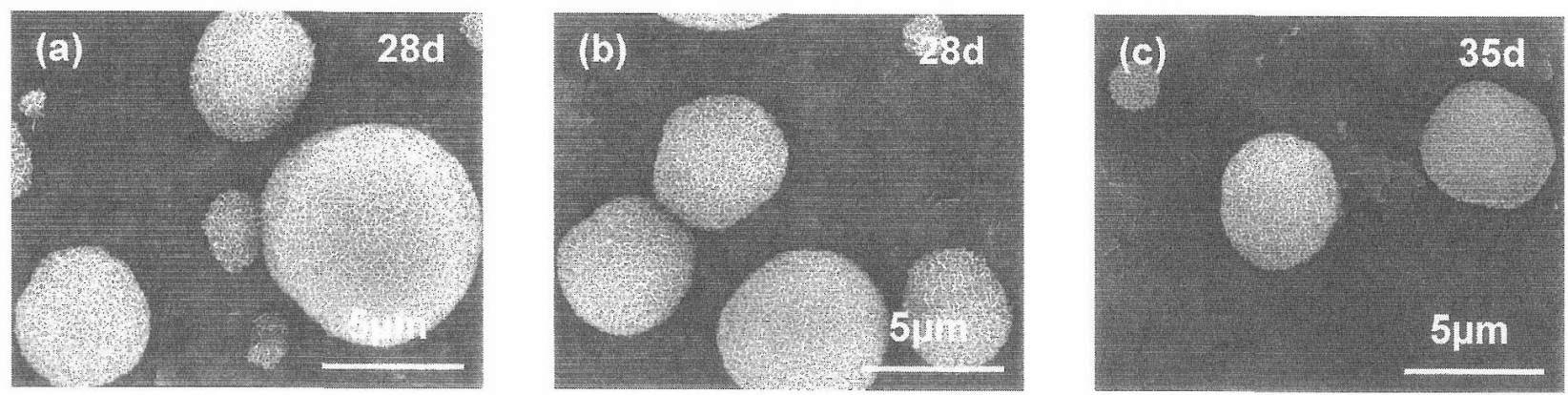

Fig. 3. The SEM images of the surfaces of the $\mathrm{PE} / \mathrm{TiO}_{2}$ composites prepared by hot-pressing of the powder mixtures obtained by (a) agate mortar, (b) ball mill, and (c) Theta-composer mixing and then soaked in SBF for $28 \mathrm{~d}$ or $35 \mathrm{~d}$. 
結晶性の低い炭酸含有の骨類似アパタイトが形成された ことが分かった。しかし，Fig. 3 に示されるように，アパ タイトは複合体表面の一部分にしか形成されず，去の後， 浸漬を継続しても全面がアパタイトで覆われなかった。そ のアパタイト形成までの誘導期間はTable Iに示す通り であり，テパタイト形成能はボールミル混合ミめのう乳 鉢混合>シータコンポーザー混合の順で高かった。

\section{$3 \cdot 3$ 研磨 $\mathrm{PE} / \mathrm{TiO}_{2}$ 複合体}

Fig. 6 に \#120 で研摩した複合体表面のSEM 写真を示 す. Fig. 6 (a)，(b)より，めのう乳鉢むよびボールミル混 合粉体から調製した複合体中では， $\mathrm{TiO}_{2}$ の凝集体は見ら れなくなったが, $\mathrm{TiO}_{2}$ は完全に均一には分散しておらず, その分布に若干の偏りが見られた。Fig.6 (a)，(b)には， その中でも若干 $\mathrm{TiO}_{2}$ が多く観察される部分を示した。 $\mathrm{TiO}_{2}$ の分布の均一性は, めのう乳鈢混合粉体よりもボー ルミル混合粉体から調製された複合体中のほうが良かっ た。一方, Fig. 6 (c)より, シータコンポーザー混合から 調製された複合体中では $\mathrm{TiO}_{2}$ が均一に分散していた。

Table I. Induction period for apatite formation in SBF for the $\mathrm{PE} / \mathrm{TiO}_{2}$ composites prepared through three different mixing processes.

\begin{tabular}{c|c}
\hline Mixing process & Induction period / d \\
\hline Agate mortar & 28 \\
Ball mill & 28 \\
Theta-composer & 35 \\
\hline
\end{tabular}

これらの研摩複合体をSBFに浸漬すると，すべて未研 磨の場合より短期間に，炎の表面全体が同様の粒子状の 形成物で覆われるのが観察された (Fig. 7)。 TF-XRD 測 定の結果, SBF 浸漬後の表面からアパタイトに帰属され るブロードなピークが検出された (Fig. 8)。未研磨の場 合に比べて，そのピーク強度は有意に高く，より高いア パタイト形成能を示した。アパタイト形成までの誘導期 間は, Table IIに示䟚りであり，アパタイト形成能の 順序は，未研磨の場合と同様であった。

Fig. 9 に, $\mathrm{PE} / \mathrm{TiO}_{2}$ 複合体浸漬による $\mathrm{SBF}$ 中のカル

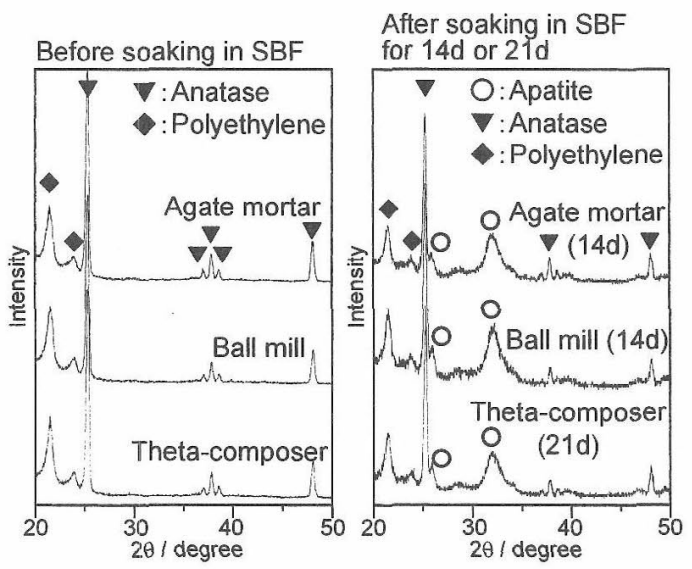

Fig. 8. XRD patterns of the surfaces of the $\mathrm{PE} / \mathrm{TiO}_{2}$ composites prepared through three different mixing processes, abraded with abrasive papers and then soaked in SBF for 14 or 21d.
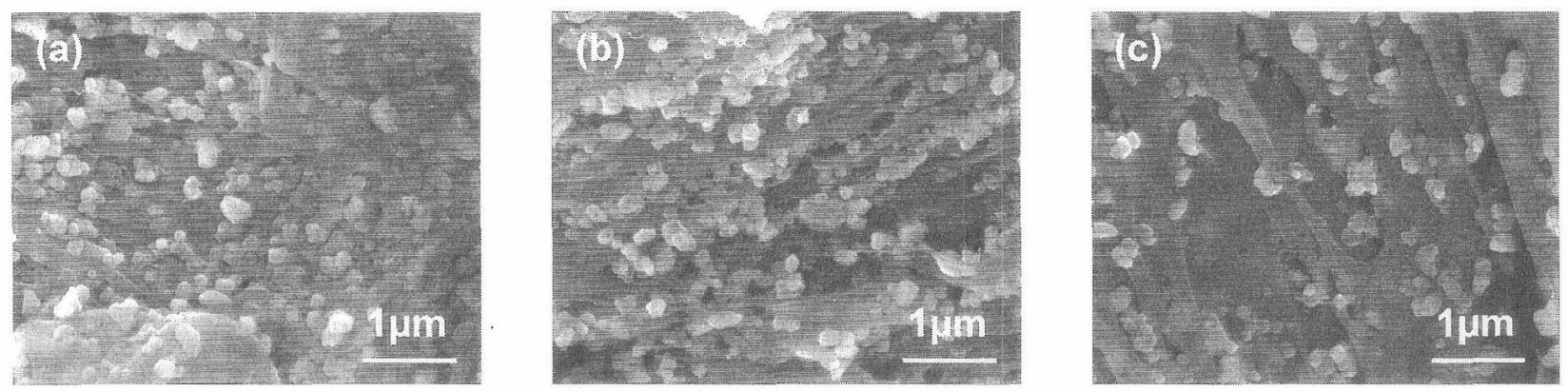

Fig. 6. The SEM images of the surfaces of the $\mathrm{PE} / \mathrm{TiO}_{2}$ composites prepared by hot-pressing of the powder mixtures obtained by (a) agate mortar, (b) ball mill, and (c) Theta-composer mixing processes and then abraded with abrasive papers.
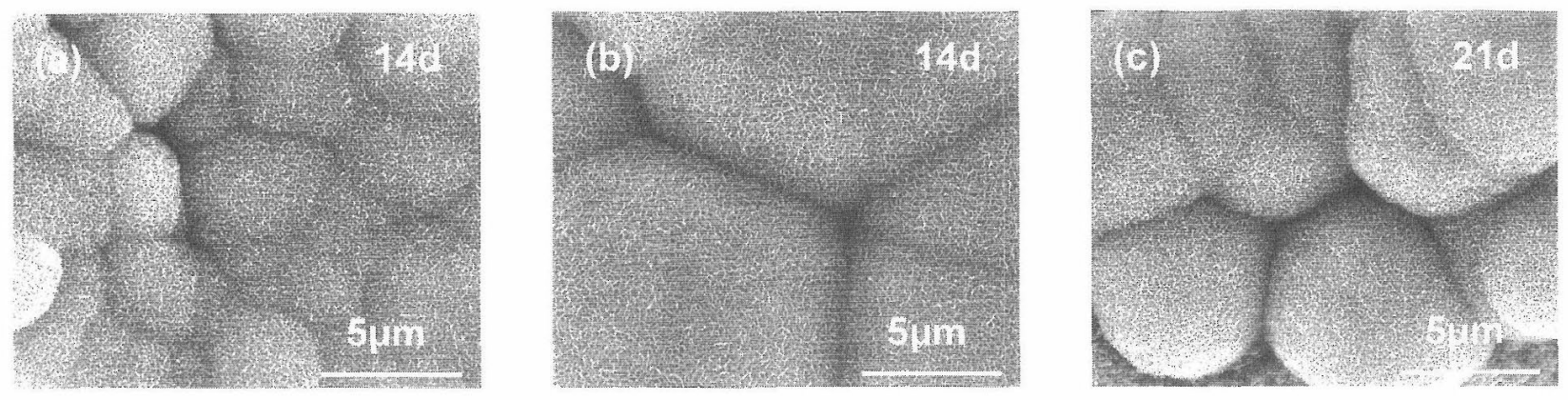

Fig. 7. The SEM images of the surfaces of the $\mathrm{PE} / \mathrm{TiO}_{2}$ composites prepared by hot-pressing of the powder mixtures obtained by (a) agate mortar, (b) ball mill, and (c) Theta-composer mixing processes, abraded with abrasive papers and then soaked in SBF for $14 \mathrm{~d}$ or $21 \mathrm{~d}$. 
Table II . Induction period for apatite formation in SBF for the $\mathrm{PE} / \mathrm{TiO}_{2}$ composites prepared through three different mixing processes and abraded with abrasive papers.

\begin{tabular}{c|c}
\hline Mixing process & Induction period / d \\
\hline Agate mortar & 14 \\
Ball mill & 14 \\
Theta-composer & 21 \\
\hline
\end{tabular}
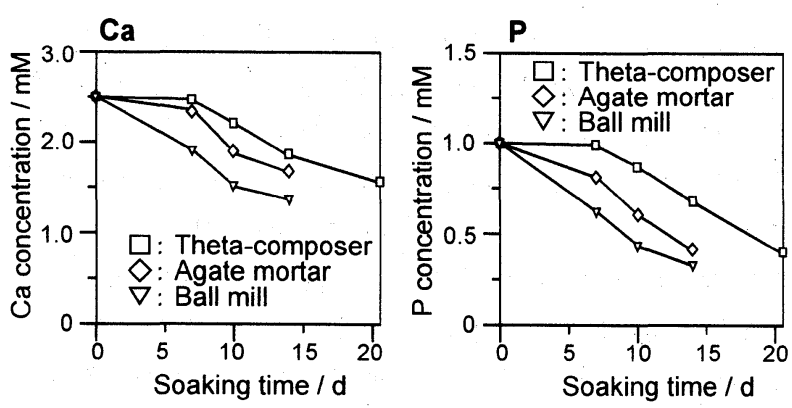

Fig. 9. Changes in $\mathrm{Ca}$, and $\mathrm{P}$ concentrations of $\mathrm{SBF}$ with soaking of the $\mathrm{PE} / \mathrm{TiO}_{2}$ composites.

シウムおよびリン元素濃度の時間変化を示す．カルシウ ムおよびリンの濃度は, SBF 浸漬時間と共に減少した。 これはアパタイト層の形成により, SBF 中のカルシウム およびリンイオンが消費されたためである。その減少の 度合いは，ボールミル混合 > めのう乳鉢混合 > シータコ ンポーザー混合の順であった.これの結果は, SEM 写真 やTF-XRD 分析で観測されたアパタイトの生成挙動とよ く一致した.

Fig. 10 に, 3 点曲げ試験で得た $\mathrm{PE} / \mathrm{TiO}_{2}$ 複合体の荷 重一変位 (たわみ) 曲線を示す. めのう乳鉢混合, ボー ルミル混合, シータコンポーザー混合の各粉末から調製 した複合体それぞれについて，代表的な曲線を示した。 比較のために, $\mathrm{TiO}_{2}$ を含まない超高分子量 $\mathrm{PE}$ の荷重一 変位曲線も示した。 めのう乳鉢およびボールミル混合粉 体から作製した複合体では，荷重一変位曲線に荷重降下 による段差が認められ，滑らかな曲線ではなかった。一

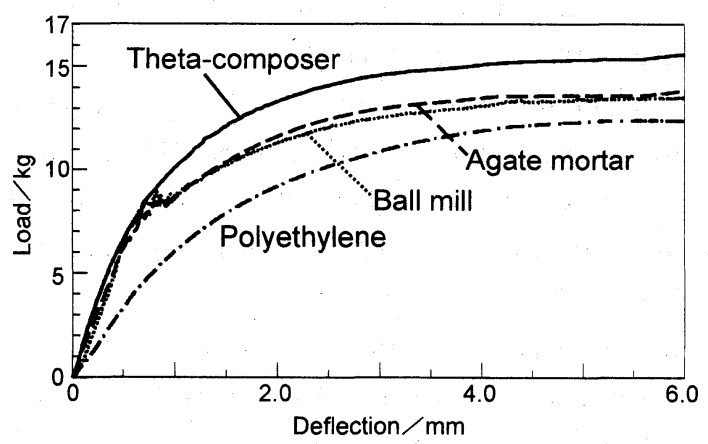

Fig. 10. The load-deflection curves of the ultra-high molecular polyethylene and $\mathrm{PE} / \mathrm{TiO}_{2}$ composites measured by three-point bending test. The representative curves are shown for polyethylene and $\mathrm{PE} / \mathrm{TiO}_{2}$ composites prepared through three different mixing processes.
方, シータコンポーザー混合粉体から作製した複合体か らは, 段差のない滑らかな荷重一変位曲線が得られた。 Fig. 10 から分かるように, PE は, 鋭い降伏点を示さず に緩やかに塑性変形に遷移し，たわみが $5 〜 6 \mathrm{~mm}$ にな ると, 曲げ荷重がほぼ一定の值に達するような挙動を示 した. PEの塑性ひずみは非常に大きく，破断に至るま での試験は，曲げ試験では困難であるので，PE および 複合体とも，たわみが $6 \mathrm{~mm}$ になったところで試験を打 ち切った。供試体の曲げ試験で得られた荷重一変位曲線 には非線形領域が含まれるため, この領域では応力 $\sigma$ と ひずみ $\varepsilon$ の間にべき乗則, $\sigma=\mathrm{H} \cdot \varepsilon^{\mathrm{n}}(\mathrm{n}:$ ひずみ硬化指 数 $(0 \leq \mathrm{n} \leq 1), \mathrm{H}$ : 定数) が成り立つと仮定して塑性曲 げ理論 $^{13)}$ を基礎に応力とひずみを評価した。 $\mathrm{n}$ は，曲げ 荷重一たわみの対数プロットから見積もった. 本報では, たわみが 5 〜 $6 \mathrm{~mm}$ になった時の最大曲げ応力を曲げ強 度と呼ぶことにする。このようにして求めた曲げ強度な らびに荷重一変位曲線の初期の線形弾性領域の傾きから 求めたヤング率の值を Table III にまとめて示す．曲げ強 度に関しては, シータコンポーザー混合粉体から作製し た複合体の強度が一番高く, PE 単独の強度よりも高か った，各複合体のヤング率は，混合法の違い関係なくほ とんど同じであったが, PE 単独の值よりも高かった.

\section{4 考察}

\section{$4 \cdot 1 \mathrm{PE} / \mathrm{TiO}_{2}$ 混合粉体}

一般的にナノサイズの微粒子は凝集性が高いうえに， 使用した $\mathrm{TiO}_{2}$ と $\mathrm{PE}$ の粒径が約 200 倍, 密度差が約 4 倍 と大きく異なるため, めのう乳鉢あるいはボールミル混 合法で完全に凝集物のない混合粉体を得ることは容易で はないことが分かった。 また，その凝集物の大きさの違 いは，ドライプロセスに比べてエタノール中での $\mathrm{TiO}_{2}$ の 分散性が良いためである。一方, シータコンポーザー混 合により， $\mathrm{TiO}_{2}$ で被覆された $\mathrm{PE}$ 複合粒子が作製できた が, ローター回転数が $2100 \mathrm{rpm} よ り$ 低いか高い場合は,

Table III. Bending strength and Young's modulus of the ultra-high molecular weight polyethylene and $\mathrm{PE} / \mathrm{TiO}_{2}$ composites prepared through three different mixing processes. Mechanical data are compared with those of cortical bone and typical ceramic biomaterials clinically used.

\begin{tabular}{lcc}
\hline \multicolumn{1}{c}{ Materials } & $\begin{array}{l}\text { Bending } \\
\text { strength } / \mathrm{MPa}\end{array}$ & $\begin{array}{l}\text { Young's } \\
\text { modulus / GPa }\end{array}$ \\
\hline $\begin{array}{l}\text { Polyethylene } \\
\text { PE/TiO }{ }_{2} \text { composites }\end{array}$ & $24.3 \pm 0.4$ & $0.80 \pm 0.03$ \\
Mixing process: & & \\
$\quad$ Agate mortar & $26.2 \pm 1.2$ & $1.09 \pm 0.07$ \\
$\quad$ Ball mill & $25.7 \pm 1.0$ & $1.08 \pm 0.19$ \\
Theta-composer & $29.1 \pm 0.8$ & $1.08 \pm 0.11$ \\
\hline Cortical bone & $50 \sim 150$ & $7 \sim 30$ \\
\hline Ceramic biomaterials & & \\
HAp & $115 \sim 200$ & $86 \sim 110$ \\
A-W & 215 & 118 \\
\hline
\end{tabular}


$\mathrm{TiO}_{2}$ が凝集するか, 容器の側壁に固着した。容器回転数 は凝集にほとんど影響を示さなかった。これは，PEに $\mathrm{TiO}_{2}$ を介して圧密, せん断力がうまく加わる時に初めて, その表面に $\mathrm{TiO}_{2}$ が複合化されることを示唆している。そ の結果，本法を用いればドライプロセスでは非常に困難 と思われたナノサイズの粉末を，凝集することなく均一 に混合することができることが分かった。

\section{$4 \cdot 2$ 未研磨 $\mathrm{PE} / \mathrm{TiO}_{2}$ 複合体}

いずれの混合粉体から調製した複合体もアパタイト形 成能を示したのは，アナタース構造を有する $\mathrm{Ti}-\mathrm{OH}$ 基に よってアパタイトの核形成が誘起されたためである。し かし，アパタイト形成期間はいずれも非常に長く，その アパタイト形成能は HAPEX ${ }^{\circledR}$ に比べて低かった。 また浸 漬を継続しても全面がアパタイトで覆われなかった。こ の原因は，複合体表面に存在する $\mathrm{TiO}_{2}$ が $\mathrm{PE}$ に覆われて ほとんど露出しておらず，アパタイトの核形成を誘起す る箇所が少なかったためであると考えられる。またアパ タイト形成能に差が生じた原因は，めのう乳鉢混合や湿 式混合で生じる $\mathrm{TiO}_{2}$ の凝集により局部的にアパタイト形 成能の高い場所が提供されたためであると考えられる。

\section{$4 \cdot 3$ 研磨 $\mathrm{PE} / \mathrm{TiO}_{2}$ 複合体}

めのう乳鉢とボールミル混合粉体から調製した複合体 中の $\mathrm{TiO}_{2}$ の分布が完全には均一でないのは，ホットプレ ス過程で PE が延伸される際に，もともと混合粉体に含 まれていたわずかな凝集体が引張られて拡散するために 分散性が向上するが, そのPEの移動距離が小さく, 完 全には均一な分散に至らなかったためと考えられる。ま た，その均一性に差が現れたのは，もともとの凝集物サ イズの小さいボールミル混合粉体の方が，拡散により均 一な分散状態になり易いためと考えられる.

いずれの研摩複合体も，未研磨の場合に比べて高いア パタイト形成能を示したのは，研磨による表面粗さの差 の影響ではなく， $\mathrm{PE} に$ 覆われていた $\mathrm{TiO}_{2}$ が露出したた めであると考えられる

めのう乳鉢抢よびボールミル混合粉体から作製した複 合体で, 荷重一変位曲線に荷重降下による段差が認めら れたのは, 複合体中に存在する $\mathrm{TiO}_{2}$ の凝集部位で微視 的内部破壊が生じたためと考えられる。一方，シータコ ンポーザー混合粉体から作製した複合体で，段差のない 滑らかな荷重一変位曲線が得られ，一番高い曲げ強度を 示したのは, $\mathrm{TiO}_{2}$ が均一に分散することで $\mathrm{PE}$ を補強し ているためであると考えられる。

本複合体の曲げ強度は，既に実用化されている $\mathrm{HAPEX}^{\circledR}$ 複合体よりも高く ${ }^{9}$ ささらに現在実用化されてい る他の人工骨に比べヒトの皮質骨のそれに近い。また本 複合体は, 従来の人工骨に比べるとはるかに大きな伸張 性を示すという特長をもっている. $\mathrm{TiO}_{2}$ 粒子の分散の効 果で, 本複合体の弾性率は, PE 単独の弾性率より高く なった。その值はヒトの皮質骨のそれにはおよんでいな
いが，現在一般に用いられている人工骨の弾性率と比較 すると，皮質骨のそれに近い值となっている， $\mathrm{TiO}_{2}$ 粒子 の分散量を増すことにより, 弾性率とアパタイト形成能 をさらに向上させることが可能であると考えられるので， 本複合体は有用な骨修復材料になり得るものと期待され る。

\section{5 結 㻅}

シータコンポーザー混合により, $\mathrm{TiO}_{2}$ で被覆された $\mathrm{PE}$ 複合粒子が作製できた。この複合粒子をホットプレスす ることにより，ナノサイズの粒子を凝集させることなく， 均一に分散させた $\mathrm{PE} / \mathrm{TiO}_{2}$ 複合体を作製することができ た。本複合体は，アパタイト形成能を示し，複合体表面 を研磨することでその表面に均一にアパタイト層を析出 させることができた，本複合体は，現在用いられている 人工骨に比べヒトの皮質骨により近い力学的性質を有し ており，有用な骨修復材料になるものと期待される.

本研究は, 新エネルギー・産業技術総合開発機構の委 託事業「内視鏡等による低侵襲高度手術支援システム」 にて行われたものである.

\section{参 考 文 献}

1) L. L. Hench, R. J. Splinter, W. C. Allen and T. K. Greenlee, J. Biomed. Mater. Res. Symp., 2, 117 (1972).

2 ) M. Jarcho, J. L. Kay, R. H. Gumaer and H. P. Drobeck, J. Bioeng., 1, 79 (1977).

3 ) T. Kokubo, M. Shigematsu, Y. Nagashima, M. Tashiro, T. Nakamura, T. Yamamuro and S. Higashi, Bull. Inst. Chem. Res., Kyoto Univ., 60, 260 (1982).

4 ) S. Nishiguchi, T. Nakamura, M. Kobayashi, H.-M. Kim, F. Miyaji and T. Kokubo, Biomater., 20, 491 (1999).

5) S. Fujibayashi, T. Nakamura, S. Nishiguchi, J. Tamura, M. Uchida, H.-M. Kim and T. Kokubo, J. Biomed. Mater. Res., 56, 562 (2001).

6 ) T. Kokubo, "Bone-Bonding Biomaterials", p.31 (1992) Reed Healthcare Communications, Netherlands.

7) T. Kokubo, H. Kushitani, S. Sakka, T. Kitsugi and T. Yamamuro, J. Biomed. Mater. Res., 24, 721 (1990).

8 ) W. Bonfield, M. D. Grynpas, A. E. Tully, J. Bowman and J. Abram, Biomater., 2, 185 (1981).

9) J. A. Juhasz, M. Kawashita, N. Miyata, T. Kokubo, T. Nakamura, S. M. Best and W. Bonfield, "Bioceramics14", p.437 (2002) Trans Tech Publications, Switzerland.

10) M. Wang, L. L. Hench and W. Bonfield, J. Biomed. Mater. Res., 42, 577 (1998).

11) J. Li and S. Forberg, L. Hermansson, 12, 438 (1991)

12) C. Ohtsuki, T. Kokubo, K. Takatsuka and T. Yamamuro, J. Ceram. Soc. Japan, 99, 1 (1991).

13) N. E. Dowling, "Mechanical Behavior of Materials", Chap. 13, p.570 (1993) Prentice-Hall, New Jersey. 